\title{
Rakkaudettomuus johti tutkimaan rakkautta
}

bell hooks (2016). Rakkaus muuttaa kaiken (All About Love. New Visions, 2000). Suom. Elina Halttunen-Riikonen. Eurooppalaisen filosofian seura ry/ niin \& näin. 179 sivua. ISBN: 978-952-5503-92-0

Bell hooksin aloitus rakkaudettomuuden kokemisesta koskettaa: "Lapsena minulle oli selvää, ettei elämä olisi elämisen arvoista ilman rakkautta. Toivon, että voisin sanoa tiedostaneeni asian elämässä kokemani rakkauden vuoksi. Mutta juuri rakkauden puuttuminen sai minut oppimaan rakkauden merkityksen."

Yhdysvaltalainen feministi ja kulttuurintutkija bell hooks puhuu rakkauden muutosvoimasta. Hän ei arkaile paljastaa henkilökohtaisia kokemuksia lapsuudestaan tai parisuhteistaan. Hän kertoo avoimesti myös hengellisestä etsimisestä ja terapiasta, jonka avulla hän oppi ymmärtämään niin lapsuuden rakkaudettomuuden tuskaa kuin aidon rakkauden kokemustakin.

Nyt suomennettu teos Rakkaus munttaa kaiken käsittelee yhteiskunnan pinttyneitä oletuksia rakkaudesta. Hooks hahmottelee yhteiskuntaa, joka vallankäytön sijaan perustuisi rakkauden etiikkaan.

\section{RAKKAUS MUUTOSVOIMAKSI}

Hooksin alkuperäisteos All about Love: New Visions (2000) käynnisti hooksin pitkän tutkimusmatkan rakastamisen teemoihin. 2000-luvun alkuvuosina julkaistuun rakkaustrilogiaan kuuluvat lisäksi Salvation: Black People and Love (2001) ja 
Communion: The Female Search for Love (2002). Rakkaus ja yhteisöllisyys ovat kokonaisuuden kantavia ajatuksia. Hooks ajattelee, että ne tarjoavat tien ihmisten lähtökohtiin liittyvien erojen ja eriarvoisuuden ylittämiseen.

Teoksessa Communion bell hooks rohkaisee kaikkia naisia etsimään rakkautta, rakastamaan kaikkia muita ja kaikkea myös itsessään: vasta rakastamisen myötä ihmisen elämä voi saada täyttymyksensä, vain se voi auttaa kasvamaan. Vuonna 2004 julkaistussa kirjassa The Will to Change: Men, Masculinity, and Love bell hooks kirjoittaa miehistä ja heidän rakkauden kaipuustaan. Miehetkin kärsivät kapitalismin heille määrittämän roolin kapeudesta.

Usko rakkauden ja yhteisöllisyyden muutosvoimaan elää vahvana myös hooksin kasvatusajattelussa, josta hän kirjoitti jo aiemmin suomennetussa teoksessa Vapauttava kasvatus (2007). Siinä tavoitteena on yhteiskunnan tasaarvon ja oikeudenmukaisuuden edistäminen osallistamisella ja yhteisöllisyyttä rakentaen.

\section{HENKILÖKOHTAINEN ON YHTEISKUNNALLISTA}

Bell hooks on erityisesti kotimaassaan suosittu ja valovoimainen persoona, jolla on mittava kirjallinen tuotanto. Hän on julkaissut yli 30 teosta. Hän on tehnyt menestyksekkään akateemisen uran toimien professorina amerikkalaisissa huippuyliopistoissa. Hän kuitenkin luopui siitä, koska koki, ettei tehokkuuden valtaa- massa yliopistossa ollut riittävästi tilaa toisinajattelulle ja uudistumiselle. Hän siirtyi ensin vapaaksi kirjailijaksi ja palasi 2000-luvulla synnyinseuduilleen Kentuckyyn, jossa hän toimii professorina kristillisessä Berea Collegessa.

Hooksin teoksille on jo pitkään ollut ominaista omaelämäkerrallinen kirjoittamistyyli, johon kuuluu omien kokemusten teoretisointi ja nivominen yhteiskunnalliseen tarkasteluun. Omakohtaisuus puhuttelee. Yhteiskunnallinen ulottuvuus taas osoittaa, miten henkilökohtainen on myös yhteiskunnallista.

Teoksen Rakkaus muuttaa kaiken rakenne noudattelee hooksille tyypilliseksi muotoutunutta tapaa, jossa kirja koostuu esseistä. Esseekokoelman voi nähdä palvelevan erityisesti sitä, että hän haluaa tähdätä tekstinsä laajalle yleisölle eikä vain akateemiselle yhteisölle.

\section{PINTTYNEET KÄSITYKSET ESTÄVÄT RAKASTAMISEN}

Bell hooks ravistelee rakkaudesta vallitsevia käsityksiä, joiden mukaan rakkaus käsitetään tunteena, se on jotain leijuvaa ja salaperäistä ja siksi myös vaikeasti määriteltävää. Hänen näkemyksensä mukaan rakkaus voitaisiin hahmottaa toimintana ja käytäntönä. Sen ulottuvuuksiin kuuluvat huolenpito, vastuullisuus, arvostus, rehellisyys, luottamus ja sitoutuminen.

Hooks ihmettelee, miksi rakkaudesta ovat kirjoittaneet vakavasti vain miehet, vaikka rakkaus ja tunteet liitetään tavallisesti naisiin. Teoksessaan hän käy keskus- telua monenlaisen kirjallisuuden kanssa, lähteet ulottuvat tunnetuista filosofeista elämäntaito-oppaisiin, new age -kirjallisuuteen ja Raamattuun. Merkittävästi hänen rakkauden määrittelyynsä näyttää vaikuttaneen etenkin kahden (mies)psykoanalyytikon teokset: Erich Frommin Rakkauden vaikea taito (1956/1977) ja M. Scott Peckin Rakkauden psykologia (1978/2012).

Hooksin ihmiskäsitys on laaja: ihminen on fyysinen, psyykkinen, sosiaalinen mutta myös henkinen olento. Yhteiskunta eroineen ja jakoineen on alati läsnä vaikuttamassa ihmisten kasvuun ja identiteettien rakentumiseen. Henkisyyden merkitys nousee esiin läpi kirjan, mutta sitä käsitellään myös omassa luvussaan. Hooks katsoo, että materialistinen yhteiskunta on kääntänyt selkänsä hengellisyydelle samoin kuin rakastamiselle. Hengellinen elämä on hänestä merkityksellistä, vaikkei se liittyisikään uskontoon. Rakkauteen herääminen on hänen mielestään aina myös hengellistä heräämistä.

Teos käsittelee painokkaasti patriarkaattia ja siihen pohjaavaa seksistisestä sosialisaatiota, josta seuraa ongelmia niin rakkauden etsimiselle kuin parisuhteillekin. Sukupuolistereotypiat dikotomisine jakoineen luovat epätasa-arvoisen valta-asetelman, jossa mies on naista vahvempi ja omaa suhteessa enemmän valtaa. Sen lisäksi niihin sisältyvä dikotomia, jonka mukaan miehet käsitetään järkiolennoiksi ja naiset tunneolennoiksi, rajoittaa paitsi molempien kasvua omaksi itseksi myös parisuhteen onnistu- 
misen mahdollisuuksia. Teoksessa kuvataan rikkaasti monenlaisia sekä ihmisten keskinäisiä että yhteiskunnallisia prosesseja, joita patriarkaatti ja seksistinen sosialisaatio osaltaan muovaavat ja joihin perustuvia sukupuolittuneita ja epätasaarvoisia elämänmalleja markkinatalous, mainonta ja populaarikulttuuri tuottavat ja uusintavat.

Hooksin feministisen ajattelun kantavana juonteena on intersektionaalisuus, erilaisten erojen yhteen kietoutuminen. Vaikka tämä teos keskittyy vahvasti sukupuolen merkitykseen, analyyseissa eivät pääse unohtumaan kapitalistinen luokkayhteiskunta ja "valkoisen herruuden ylivalta". Hooksin feminismissä sukupuoli koskee selvästi molempia sukupuolia. Hän kohdistaa puheensa sekä naisille että miehille, sillä rakkauden ja parisuhteiden maailmassa molemmat ovat patriarkaalisen sosialisaation kohteita, ja opitut sukupuolistereotypiat tekevät rakkauteen perustuvan yhteiselon parisuhteissa lähes mahdottomaksi. Eritoten hooks kritisoi sitä, miten patriarkaalisessa kulttuurissa miehet joutuvat tukahduttamaan tunteitaan ja herkkyyttään pienestä pitäen.

\section{MISSÄ LAPSI OPPII}

\section{RAKASTAMAAN?}

Yleensä ajatellaan, että rakastamaan opitaan perheessä. Hooks puhuu elämästään lapsuuden perheen rakkaudettomassa il- mapiirissä mutta yleisemminkin yhteiskunnan pahoinvoinnista ja siitä, miten yhteisöllisyyden kadottaneet ydinperheet toimivat ihmissuhteissaan. Jäykkiin sukupuolistereotypioihin perustuvat elämänmallit varjostavat perheelämää ja lapsen kasvuympäristöä. Rakastamaan oppimisen sijaan hän oppiikin vääränlaisia käsityksiä toimivasta kommunikoinnista ja yhteisöllisyydestä. Yhteiskunnalliset instituutiot, kuten koulu, taas rajaavat yksityisen elämänalueen taidot opetuksen ulkopuolelle. Siten rakastamisen taitoja joudutaan opettelemaan romanttisin rakkauskäsityksin omassa parisuhteessa niillä eväin, joita kotoa on ammennettu.

Rakkaus muuttaa kaiken on osuva nimi teokselle. Sitä juuri kirjassa tavoitellaan, rakkauden etiikalla toimivia ihmisiä, yhteisöjä ja yhteiskuntaa. Itseäni viehättää toiveikas visio, että rakastaminen on tie tasa-arvoon, yhteisöllisyyteen ja hyvinvointiin. Teos ei ole elämäntaito-opas, mutta kelpaa hyvin siihenkin. Sen suomentamista voi pitää tärkeänä palveluksena, jolla saatetaan bell hooksin innostavat pohdinnat rakkaudesta paremmin lähestyttäviksi suomalaiselle yleisölle.

Bell hooksin maalaileva puhe, taito yhdistellä asioita ja voimakas ilmaisutapa ovat vetoavia. Olisin kuitenkin kaivannut tarkempia lähdemerkintöjä, etenkin koska lähteiden käyttö on varsin eklektistä. Hooksia onkin jo pitkään arvosteltu siitä, ettei hän noudata totuttuja lähdemerkintätapoja ja sisällytä teoksiinsa kirjallisuusluetteloita. Hän on puolustanut tätä sillä, että haluaa kirjoittaa akateemista yhteisöä laajemmalle yleisölle.

Kirjaa aloittaessani luulin tietäväni, mitä rakkaus on, mutta lukiessani tunnistin käsitykseni kapeaksi. Ymmärrykseni lisääntyi ennen muuta siitä, mitä kuvitellaan rakkaudeksi ja miten yhteiskuntaan ja kulttuuriin syvään juurtuneet käsitykset ja normit tekevät rakastamisesta vaikeaa.

Marjo Vuorikoski

KT

\section{LÄHTEET}

Fromm, Erich (1977). Rakkauden vaikea taito (The Art of Loving, 1956). Suom. Matti Luoma \& Marja Matikainen. Helsinki: Kirjayhtymä. hooks, bell (2001). Salvation: Black People and Love. NY: Harper-Colllins Publishers.

hooks, bell (2002). Communion. The Female Search for Love. NY: HarperCollins Publishers. hooks, bell (2004). The Will to Change: Men, Masculinity, and Love. NY: Atria Books.

hooks, bell (2007). Vapauttava kasvatus. Toim. Marjo Vuorikoski \& Hilkka Rekola. Suom. Jyrki Vainonen. Helsinki: Kansanvalistusseura.

Peck, M. Scott (2012). Rakkauden psykologia (The Road Less Traveled - The New Psychology of Love. Traditional Values and Spiritual Growth, 1978). Suom. Anna-Liisa Kuusela. Helsinki: Kirjapaja. 